Journal of Applied Sports Seiente

September 2015, Volume 5, No. 3

Physical Activity in Sedentary Society: Active Ways of Iransportation in Czech Republic.

\title{
Aleš Sekot
}

Faculty of Sport Studies, Masaryk University, Czech Republic.

\begin{abstract}
Physical activity of people plays increasingly more important role in scientific interest regarding way of life of contemporary society. It is also very important factor in the process of officiating of the level of healthy and active life style, quality of life and health in general and also in context of prevention of obesity .

The term physical activity (PA) is mostly perceived as a synonym to the term healthy "active lifestyle", or more precisely as lifestyle linked with regular whole life motoric activity. As a such active lifestyle is a system of important activities and relations and associated practices focused on reaching undepreciated and harmonic state between physical and mental aspect of human being. Active transportation, as an indispensable part of healthy active way of life refers to any form of human-powered transportation - walking, cycling, using a wheelchair, in-line skating or skateboarding. In Czech context, from the perspective of active ways of transportation to his/her work, most respondents prefer ,, inactive ways of transportation" (cars, public transportation system); only less that one quorter of respondents use active ways of transportation (walking, biking). Men are more interested in biking, women in walking. Strong resistence against active ways of transportation to work is typical for young people in their early twenties .
\end{abstract}

Keywords: Physical activity, sport, active way of life, individual transportation.

\section{Introduction:}

$\mathrm{T}$ he position of physical and sportive activity in contemporary Czech society is co-determined primarily by the nature of its post-transformational process and its ability to absorb the relevant legacy of the past and anticipate the development trends of the future. There is no doubt that even in this context one can say that sport is the same as society. As the individual widely stretched levels of sport, a performance-oriented and success-focused Czech society puts stress particularly on performance, victory, records and material gain. In many respects, a number of important partial fights were won (successes at the top levels), nevertheless, we are loosing the most important battle: we are failing to ensure that the invigorating effects of regular, high-quality and life-long physical activities on health, fitness and morals are accessible to the masses. As a result of political and economic changes which occurred in the Czech Republic two decades ago, all areas of society started to be restructured. Naturally, this process also included public administration having responsibilities for many areas of the people's lives, including sport. This new way of "public matters provision" started at the beginning of the 1990s and culminated in the period of 2000-2002 (Kovár 2001; Staněk and Flemr 2007; Hobza 2007).

To summarize the situation of opportunities for regular and safe sportive physical activities in public territory in the Czech Republic the financial limitations and political priorities play very important role, as well as professional competence and personal preferences of particular councilors: The access of the general public to the sport facilities often collides with the clearly commercial use of the facilities (Staněk, Flemr, 2007, 294 - 297).

The levels of physical activity (PA) and sedentary behaviour are significant indicators of health behaviour and their monitoring in the context of way of life in „sedentary society“ loosing fundamental demands and requests for hard physical work and physical activities. Physical activities in general in our cultural settings are fading away from most professions, in keeping our households and in individual ways of transportation too. Walking and biking as typical healthy outdoor activities save money, provide mobility choices, free up road space, reduce pollution and promote economic vitality. In other words, for communities to thrive, trails and other safe walking and bicycling opportunities are absolutely essential (Buis 2000).

Phenomenon of physical activity is many-sidedly affair connected with the concept of a healthy life style. Decision about whether to adopt a healthy lifestyle reflects personal attitudes and value preference and thereby includes an aspect of personal choice. But factual personal choice has many preconditions with social position and cultural quality of people and with the access to resources of full range of choices regarding sportive activities. We can conclude: Healthy lifestyles are patterns of voluntary 
behaviours based on choices from options that are available to people according to their life situations (Cockerham, Rutten and Abel, 1997, Vanreusel and Meulders 2007).

\section{Conceptual discussion}

To discuss properly the topic of growing importance, state and condition of physical activity in context of active ways of transportation, requires conceptual delimination of relevant key concepts as life style, quality of life, active health, physical activity, exercise, sport, physical fitness and active ways of transportation. The concept of life style is highly complicated phenomenon, which could be approached from various perspectives. On the ground of sociology is very closely connected with relevant concepts as way of life (reflecting characteristic nature and features of given society), style of life (descripting individual personal attitude to his/her life), or quality of life (Honzík, 1965, Dufková 2007, Valejt 2014?).

There still is no consensus in defining the terms if style and lifeway in scientific literature to this day. The term active lifestyle is perceived mostly as a synonym to the term "healthy lifestyle", or more precisely as lifestyle linked with motoric activity (Buriánek, 1996; Duffková, 2005; Kubátová, 2001, Ivanovová, 2006; Jansa, 2005, Bunc and Štilec 2010). From strictly academic perspective the concept of life style reflects structured system of habits, customs, traditions and norms in interaction with relevant material surroundings (Velký sociologický slovník, 1996, p. 1246).

From our point of view we speak about such side of life style, which, beside active approach to professional, family and societal obligations and duties, includes also regular long-life sportive physical activities and correct and regular eating habits as an integral part of all-out devoloped individual (Krejčík, 2006; Cooper 1996). And just in such context an utilizing and aplication of active way of personal transoprtation corresponds and is in accord with such attitude to life.

Exercise: Any structured and/or repetitive physical activity performed or practiced where the main intention is to achieve improved physical fitness (Pink 2008, p. 3). . In such context a convergence of opinion regarding exercise is reminded:

- "pre contemplation" with no mind to become more active

- "contemplation"

- "preparation" for exercise

- "action" - taking the appropriate exercise
- "maintenance" - to last a lifetime with dropout and resumption (Morris and Hardman 1997, p. 327).

Sport: An activity involving physical exertion, skill/or eye-hand coordination as the primary focus of the activity, with elements of competition where rules and patterns of behaviour governing the activity exist formally though organizations. "It is institutionalized physical activity motivated with improving individual shape, personal experience or performance, results and reward objectives"(Sekot 2008, p. 10).

The relevant concept physical fitness is a complex phenomenon that is difficult to define in the context of health. It can be conceived as a set of attributes that people have or achieve and that relate to the ability to perform physical activity (Casperson et al., 1985). From another perspective it is a set of health (i.e. cardiorespiratory endurance, muscle strength, flexibility) and performance related (i.e. skill, speed, dexterity, mental concentration) attributes that people have in relation to their ability to perform physical activity (Pink 2008, p. 5).

This defined, physical fitness includes discrete components such as aerobic (or cardio respiratory) fitness, muscle strenght, muscle power, flexibility, agility, balance, reaction time and body composition. The physical fitness component usually associated with fitness is aerobic fitness and another components are related to it (Krejčík 2006).

Highly topical and up-to date concept relating to physical activity and active lifestyle is theoretical concept "active health" constructed up to the theory and its practical impacts known as "aerobic programme for active health" (Cooper 1986). It is mostly in the USA known coplex of recommendations for regular physical excercise, healthy eating habits and psychical and mental wellbeing. As first step for to such objective figures regular intensive aerobic physical activities, second step is rooted in suitable nutrition and third prerequisite for active health is proper sleeping regime and reasonable active ways of leisure. The jogging, walking, swimming, countryside skiing and biking is highly recommended in this context. It is evident that active way of style grants to personal life the proper sense, improves the quality of life and decreases respective medical expense of healthy complications and subsequent social care (Pratt 2010, p. 23). Another benefit of an active way of life is better digestion, healthy sleep and mental appeasement (Slepičková, 2001) as an integral part of harmonic state between physical and psychological side of individual (Dufková 2007). 
Afterwards we defined active lifestyle as a system of important activities and relations and associated practices focused on reaching undepreciated and harmonic state between physical and mental aspect of human being. Sedentary behavior compared with active lifestyle is clasified according to time per day sitting at the desk, sitting with friends, travelling by car, using public transportation ab the bus, train as well as fading, playing games (cards etc.) or watching television, including the time spent for sleeping (Hamř́ík et al, 2013).

Active transportation refers to any form of humanpowered transportation - walking, cycling, using a wheelchair, in-line skating or skateboarding. There are many ways to engage in active transportation, whether it is walking to the bus stop, or cycling to school/work. Active way of transportation are integral way of active way of life as basic attitude to acquiring healthy way of life (Cooper, 1996; Jansa 2005; Kováč 2001; Litman 2002) in comparasion with effect of physical inactivity as an agent of major non-communicable diseases worldwide (Lee et al, 2012).

\section{Walking and biking - natural way to develop and sustain physical fitness}

Active transportation (also called nonmotorized, humanpowered or walk/bike transport)

includes travel modes such as walking, cycling, skating, skiing, and manual wheelchairs.

Active transportation can provide a variety of benefits to individuals, businesses and

governments, particularly when it substitutes for motorized travel: More active transport improves physical fitness, and provides additional benefits when it reduces

motor vehicle traffic.

Active transportation includes many active modes and methods of travel such as:

- walking/jogging/running;

- cycling;

- in-line skating;

- $\quad$ skateboarding;

- $\quad$ non-mechanized wheelchairing;

- $\quad$ snowshoeing/skiing;

To discuss the topic of active ways of transportation means to speak above all about walking a biking.
We walk to get from A to B, but also for pleasure and companionship, to talk, reflect, unwind, clear the brain, calm the nerves a lift the spirit, for exercise and fitness. The benefits of regular walking will also be apparent and perhaps indistinguishable from its social context, through its easing of roles and relations which prevents isolation. It is plausible that "fairly brisk" walkers, aged 55 to 73 years, were regularly engaging in sufficient dynamic aerobic exercise which, although below the generally hypothesised "vigourous" and was inducing and sustaing endurance fitness and lowering their coronary incidence (Morris and Hardman, 1997, p. 320). As it is generally stated: "I have two doctors, my left leg and my right leg". Anyway, walking is the natural form of getting about and the commonest exercise. By contrast with running, one foot is always in touch with the ground, and, whatever the pace, walking makes low impact, minimising strain on feet and joints, and thus the risk the injury (Sutherland et al., 1993, p. 23). During a walk, as in other forms of aerobic exercise with the body's large muscles, e.g. swimming or cycling, there are important changes in cardiovascular and respiratory functions. In this context we accent the generally known fact that fitness increases with training and declines with inactivity. Training is defined as exercise, regularly performed over weeks and months, which exceeds in intensity, and/or frequency and duration, that to which the individual is accustomed. Walking is one of the few feasible exercise regiments in the treatment of overweight individuals, gains in fitness are particularly valuable for the elderly and can be proportionately as large as those at younger ages.

Walking is convenient and may be accommodated in occupational and domestic routines. It is self regulated in intensity, duration and frequency, and, having a low ground impact, is inherently safe. Unlike so much physical activity, there is a little, if any, decline in middle age. It is a year-round, readily repeatable, self-reinforcing, habitforming activity and the main option for increasing physical activity in sedentary populations. Walking is ideal as a gentle start-up for for the sedentary, including the inactive, immobile eldery, bringing a bonus of independence and social well-being (Sælensminde 2002).

It is indisputable that walking is natural part of our lives reflects also quality and character of our environment. Heavily polluted air, the dirt and smell of traffic, are already a deterrent to walking.

Walking is generaly most natural, and most frequent traditional way of human physical activity and historicaly most typical way of transportation. Walking is also the most common and most natural weight-bearing activity engaged and involved in a form of acute, short term effects 
of the exercise, or in chronic, cumulative adaptations depending on habitual activity over weeks and months (Morris and Hardman, 1997, p. 307).

Walking is the most natural activity and the only sustained dynamic aerobic exercise that is common to everyone except for the seriously disabled or very frail. No special skills or equipments are required. Walking is convenient and may be accommodated in occupational and domestic routines. It is self regulated in intensity, duration and frequency, and, having a low ground impact, is inherently safe. Alternatively, walking can be suggested as very effective means for personal motivation, clinical practice, and publiuc health (Rzewnicky, 2003; Morris and Hardman, 1997; Litman, 2002).

Walking as an individual way of transportation is supported with diversity of the landscape scenery and closeness of acceptable, confortable and secure opportunities for walking in everyday rituals to transfer to work as well as to walk for shopping or for amusement and recreation. Attractivity of walking is supported namely in attainability of walking opportunities at maximum distance of 5-10 minutes from our places of residence. World Health Organization focuses on children and older people presenting walking as a form of active life through everyday transport. (WHO 2003, Nelson et al. 2007; Neuls 2010).

In our cultural settings the growing popularity of $c y c l i n g$ is reflected mostly as a form of active leisure physical activity; not preferably as an individual way of transportation. In the Czech Republic driving the bike is mostly popular as a pleasure sportive activity, unlike in meny West European counries, prefering the bike as an economical and ecological way of individual transportation to work, to school, for to visit fiends, for shopping. In this context it is inevitable to take in an account that general comfort of cycling routes and paths is improved with growing standards of security for broad spectrum of their users (Janežič et al., 2010, p. 49).

Driving the bike from the perspective of physical activity and positive healthy impacts is more effective comparing with walking: more big skeleton muscles are utilized, frequency of physical effort is more natural, preventive health effects are unquestioned: regular biking decreases mortality by $40 \%$ (Anderson et al, 2000; p. 1621 -1628). At the same time compared with run biking is less claiming to physical strain (Vondruška and Barták, 1999). It is comprehensible that sufficient amount of attainable "green" cyclo lines and cyclo paths is indispensable factor of mass cycling activity as an important part of active way of life (Charriere et al., 2010, p. 28). In some countries (Danemark, Netherlands, Germany, England) growing tendency to use the biking as active way of individual transporatation to work and to school is mentioned (Cahil, N. Et al. (2010).

In the context of motivation to active way of life and to active physical activity mass free access to cyclo paths and cyclo tourism in general is supported (Kahn et al., 2002; Schwarzhoffová, 2010, p. 39). The general system of traffic transportation in Czech Republic still does not absorbed in sufficient ways an effective conception supporting walking and biking as an integral part of individual ways of transportation. Despite the existence of official strategic measures supporting benefical individual as well as economical and ecological aspects of walking and biking as an integral part of communal policy in several European countries (Danemark, Nederlands, Great Britain, Austria, Slovenia). From the perspective of the steps supporting regular physical activities the great importance is awarded namely using bikes nor only as a modern form of leisure sportive activity but as well as the natural alternative to travel to school, work, for shopping, to go from point A to point $\mathrm{B}$, from one housing zone to another one. Very effective part of such strategy is also the tendency to build up in cities the system of public lending bike parking places reflecting also the progressive aspects of given community structure. In this context we can remind the fact that nearly all agree that basic infrastructure like roads, water, sewer systems are integral pieces of effective functioning of active transportation, Also to built up the safe places for people to walk and bike are more universally understood to be necessary for a successful 21 st century community.

Communities certainly can exist without active transportation networks, but they do not function as well. Such communities lack access to free, healthy outdoor activities that save money, provide mobility choices, free up road space, reduce pollution and promote economic vitality. In other words, for communities to thrive, trails and other safe walking and bicycling opportunities are absolutely essential. (Jackson and Kochtitzky, 2001; Littman 2002, 2002a; Buis 2000). There are many ways to engage in active transportation, whether it is walking to the bus stop, or cycling to school/work. There are numerous usual and customary benefits from active transportation:

- Health - Active transportation provides an opportunity to be physically active on a regular basis.

- Social - Active transportation increases social interactions.

- Transportation - Active transportation reduces road congestion. 
- Environmental - Active transportation is environmentally-friendly and can contribute to reductions in greenhouse gas emissions.

\section{What Affects Active Transportation?}

Active transportation declined over much of the last century, but in recent years this decline leveled off and is reversing in many communities. There appears to be significant latent demand for active transport, that is, people would walk and cycle more if they have suitable facilities and support. This suggests that improving conditions for nonmotorized travel can increase active transportation, and benefit individuals and communities overall. Various transport and land use factors affect the amount of active transportation that occurs in a community. These tend to have synergistic effects (their total impacts are greater than the sum of their individual impacts), so an integrated program that combines several strategies tends to be more effective at increasing active transportation than implementing just one or two of these strategies (Jackson and Kochtitzky 2001; Litman 2002).

Pedestrian and bicycle planning plays in nonmotorized planning and investments importatn role when improves construction of sidewalks, crosswalks, paths, bikelanes, bikeracks and other facilities removing barriers to walking and cycling and resulting in more active transportation. Social marketing in this context refers to community-based programs to encourage more socially desirable behavior. Social marketing is effective at achieving behavior changes that people generally support but find difficult to make, such as actions that increase personal health or benefits neighbors. It helps people reconcile their actions with their beliefs, providing integrity and pride, as well as helping to solve specific personal and community and neotraditional neighborhood communications (Friedman et al 1995).

\section{Active ways of transportation in Czech perspective: Methodology and research results}

The crucial topic "walking and biking in the Czech sociological perspective" means also to present some important facts on physical and sportive activities of Czech population. At this context we also have to remind the fact, that the existing whirlwind of changes associated with way of life and standard of living regarding working activities, nutrition, housing, environment, transport, leisure, travelling etc. have with no doubt strong impact at a physically active lifestyle. We live in the cultural setting adoring youth, beauty, healthy and sexy body and top physical performance. Unfortunately, images of fit and healthy attractive personalities and widely circulated health messages have not translated effectively into increased physical activity for most Czech people. Sportive activities are more less rather the manifestation of „up to date"style of life, then as an integral part of everyday life. It is for more and more financially prospering people in good social position the expression of the prosperity and the ability to freely spend and choose independently their leisure (Rychtecký 2007; Hamrík et al. 2012; Hamrík et al. 2013; etc.).

People prefer, in general, passive form of leisure, watching sport rather then doing sport. The sedentary living beset contemporary Czech society, as identically U.S. and plenty of European societies too. In such situation we are more and more confronted with pressing questions: "Why do people who know they should be more physically active still fail do so? What form the obstacles to achieving a more physically active lifestyle? And very pragmatic question is brought up to date: Is it in sedentary postmodern virtually oriented life possible to transform contemporary people into a more physical active society? What is the real prospect of our endeavour to create a social structure more conductive to a healthier society? Is it possible to overcome persistently questioned limitations found in many of the traditional approaches to promoting physical activity? Are we able to work effectively on the way of innovative strategy to increase physical activity at home, at school, and within the community" (Sekot, 2008)? Post industrial (or) post-modern society characterized in involvement in momentary short term experience, refusing traditional and long term values, is not favourable place and supportive cultural context for a transformation to physical activity both at the societal and individual level. Also the public policy makers have not sufficient attention to public and health preventive medicine and healthy lifestyles. Our chance to achieve a physical active society as an integral part of healthy life style could be improved if we can accept the challenges of truly healthy lifestyles available to all members of society, or at least for most part of society (McElroy 2002; Krejčík, 2006).

The research „Physical activity (inactivity) of Czech inhabitants "organized during the period 2012 - 2013 by Masaryk university, Brno, being now in progress in the perspective of representative research data on sportive and physical activity in context of fundamental demographic indicators: sex, age, education, nature of occupation, domicile. 5876 respondents older then eighteen, 3032 men and 2844 women, from all parts of the Czech Republic. Respondents were addressed during special actions organized as a part of project investigated with real standards of physical activity (inactivity) of current adult Czech population and using standardized adapted questionary „International Physical Activity 
Questionnaire“ (Craig et al., 2003). Main criterions for to classify the physical activity were the intensity and frequency of different levels of physical activities, as well as walking and biking. Basic informations as the place of the residence, age, education, family status were part of the questionary. Statistical analysis of relevant research data was processed via systém Statistica 12 by Statsoft. Basic statistical charateristic were included into contingental tables (Sebera, 2014, p. 50 - 52).

The signifiant indicator of frequancy and intensity of physical activities is also existence of individual ways of transfer to work. It was mentioned that we are in sedentary society confronted with great decline of physical activity in work, households and in transportation too. The discussed research in this context found that respondents in given altertatives (public transportation, car, walking, biking) prefer ,inactive ways of transportation“: public transportation and car, only one quarter or respondents prefer walking or biking (Sekot and Sebera 2014, p. 56 60): Particular data of presented research suported hypotesis on growing popularity of leisure physical activities of more educated people, high level of preference of walking in senior age groups and general tendency to sedentary occupations and professions (Sekot and Sebera 2014, p. $82-83$ ).

From the perspective active healthy way of life just at the moment the regular walking and biking pertains to most natural, most ecological, most economical and most attainable forms of physical activities. However above presented research confirmes rather contrary results: prevailing physical inactivity and prefering passive ways of transportation: Walking and biking as a form to transfer to work is practicised marginaly; younger generations have strong tendency to use car for transfer to work, bikings as the reflection of personal "sportive image“. Regarding gender the research results offer following data:

\begin{tabular}{|c|c|c|c|c|c|c|}
\hline Gender & Walking & Biking & $\begin{array}{c}\text { Public } \\
\text { transportation }\end{array}$ & Car & No & Total \\
\hline Women & 545 & 169 & 1122 & 683 & 507 & 3026 \\
\hline$\%$ & $56,71 \%$ & $35,88 \%$ & $60,26 \%$ & $38,59 \%$ & $62,90 \%$ & \\
\hline$\%$ & $18,01 \%$ & $5,58 \%$ & $37,08 \%$ & $22,57 \%$ & $16,75 \%$ & \\
\hline Men & 416 & 302 & 740 & 1087 & 299 & 2844 \\
\hline$\%$ & $43,29 \%$ & $64,12 \%$ & $39,74 \%$ & $61,41 \%$ & $37,10 \%$ & \\
\hline$\%$ & $14,63 \%$ & $10,62 \%$ & $26,02 \%$ & $38,22 \%$ & $10,51 \%$ & \\
\hline TOTAL & 961 & 471 & 1862 & 1770 & 806 & 5870 \\
\hline
\end{tabular}

From the perspective of active ways of transfer to work women prefer more walking, men are more enthusiastic with biking. Detailed data revealed the fact that women in $37 \%$ prefer public transportation (men $26 \%$ ); men prefer individual transportation by car $(61 \%)$. From the perspective of active ways of transportation women prefer walking $(57 \%)$, men are more active in biking $(65 \%)$. Men in general are more enthusiastis about individual transportation (car, bike), women prefer public transportation and walking.

From the perspective of most important research results we can summarize (Sekot and Sebera 2014, p. 53 - 95):

- active way of transfer to work is practicised with one quorter of respondents;

- walking and biking to work is more popular in small towns offering job opportunities and not offering public system of transportatation;

- youngest and oldest generations are not interested enough in walking and biking;
- women preffer public system of transportation to work, men preffer cars;

- $\quad$ walking and biking is only marginaly prefered in big towns with developed system of public transportation;

- regular walking is more popular in more educated respondents;

- biking is more popular as a form of leisure sportive activity than active way of transfer to work

\section{Conclusions}

Mutual relations of sport and society are mostly and visibly reflected in mediated television top sport events. In this context we face typical reflection of passive consumerism of sport as an important part of mass culture: people (society) expect from sport top performance, exciting show compensating monotonic course of everyday life. Society also found in top sport refreshing source of patriotism and medial celebrities, stars, icons 
and heroes as a target of mass admiration in situation of their absence in the rest of society (Smart 2005). The existence of sedentary way of life detracts general level of physical/sportive activities in everyday life of mass of people; growing importace of active way of life and an imperative of responsibility for individual health improves phenomenon of human wellbeing. People responsible for his/her physical and psychical good shape expect from regular physical activities an indispensable source of wellbeing, respect of their surroundings, and - the last and not least - his/her self-respect.

Phenomenon of physical/sportive activity is many-sided phenomenon connected with the concept of a healthy life style. Life style behaviours in general are significantly determined by But decision about whether to adopt a healthy lifestyle reflects personal attitudes and value preference and thereby includes an aspect of personal choice.We can conclude: Healthy lifestyles are patterns of voluntary behaviours based on choices from options that are available to people according to their life situations. In developed post industrial countries the members of upper and middle class by way of active lifestyle mostly reflect their value self identity accenting balanced share of an intellectual and a physical activities. It is a tendency to evaluate good health as a personal value to be sought and cultivated for one's own benefit, such as experiencing increased vitality and enjoyment of life. Lower-class individuals, with reference to the nature of their work activities and income, are less optimistic to ovoid poor health and thus are less apt to participate in systematic health promoting activity (Rzewnicky 2003).

Phenomenon of physical activity in the context of active ways of transportation is closely related to urbanisation of sports facilities, included with waking routes and cyclo paths. In such context it is useful to describe and analyse the most important milestones in the history of cityplanning (urbanisation) in the area of sport facilities. The rapid housing and industrial development is resulting in numerous urban-architectural and moreover sociological issues (Staněk, M., Flemr, L. 2007). Sport facilities planning, creating, developing and managing should be considered to be one of the strategic points in public (administration) on both the local and state level (Flemr 2007).

Results of presented research data and pilot studies imply that the individual municipal authorities in the pertinent town areas attach a diametrically different importance to sport and sporting activities. A large difference is already visible in the managing of sport and sporting activities within the organizational structures of the municipal authority (Staněk, M., Flemr, L. 2007). The most critical policy area on physical/sportive activity is the sole fact of sedentary nature of contemporary society: Very high level of prestige of sport and sportive activities in Czech society is incompatible with very low level of practical regular physical or sport activities; this tendency is also reflected in the field of popularity of active ways of transfer to work in the form of walking and biking.

\section{References}

1. Anderson, B. et al. (2000). All-cause mortality associated with phyical activity during leisure time, wokr, sport a cycling to work. Archives of Internal Medicine 16O(11).

2. Buis, J. (2000) The Economic Significance of Cycling; A Study to Illustrate the Costs and Benefits of Cycling Policy, VNG uitgeverij (www.vnguitgeverij.nl) and Ice (www.cycling.nl), 2000. Centre for Alternative and Sustainable Transport (CAST)

3. Caspersen, C. J., Powell, K. E. And Christerson, G, M, (1985). Physical activity, excercise and physical fitness. Public Health Reports. Vol. 1 (2), p. 125 131.

4. Bunc, V., Štilec, M. (2010) „Aktivní životní styl a jeho determinanty u seniorů."

5. http://www.alzheimer.cz/?PageID=590

6. Cahil, N. et al. (2010). Increasing cycling in six towns in England: A cost-effective

7. investment. Gymnica, vol. 40, no. 30, p. 105. Olomouc: Univerzita Palackého.

8. Coakley, J. (2001). Sport and Society: Issues and Controversies. New York: McGraw-Hill.

9. Cockerham, W; Rutten, A. and Abel, T. (1997). Conceptualizing contemporary health lifestyles. Sociological Quarterly, 38, 321-342.

10. Cooper, K. (1996). Aerobický program pre aktívne zdravie. Bratislava: Šport.

11. Craig, C.L., et al. (2003). International physical activity questionnaire: 12 country reliability and validity. . Medicine and Science in Sports and Exercise. 35 (8), p. 1381-1395.

12. Duffková, J. (2005). “Životní způsob/styl a jeho variantnost”. In.: Aktuální problémy

13. životního stylu. Sborník referátů a příspěvků ze semináře sekce sociologie integrálního

14. zkoumání člověka a sekce sociologie kultury a 
volného času. Praha: Masarykova česká

15. sociologická společnost při AV ČR- Univerzita Karlova v Praze.

16. Duffková, J. (2007). Sociologie životního stylu. Skriptum pro Policejní akademii. V tisku.

17. Hendl, L. and Dobrý, L. et al. (2011). Možnosti hodnocení a ovlivnění pohybové nedostatečnosti. Praha: Karolinum.

18. Ivanová, K. (2006). Životní styl jako sociální determinanta zdraví. Rigorózní práce. Praha:

19. FF- UK.

20. Jansa, P. (2005) "Sport a pohybové aktivity v životním stylu české dospělé populace (18- 61 a

21. více let).” Pp. 7-82 In.: Sport a pohybové aktivity v životě české populace. Praha: FTVS UK.

22. Janežič, M. et al. (2011). Safety cycle trainig course in the framework of European project Lify cycle. Gymnica, vol. 40, no. 30, p. 49. Olomouc: Univerzita Palackého.

23. Krejčík, V. (2006). “ Základní principy zdravého životního stylu - sport a strava."

24. http://www.ceskenoviny.cz/magazin/cviceni/index_vie w.php?id=191306

25. Friedman, B; Gordon, S. and Peers, J. (1995). Effect of Neotraditional Neighborhood Design on Travel Characteristics," Transportation Research Record 1466, 1995, pp. 63-70.

26. Hamř́k, Z., Kalman, M., Bobáková, D. and Sigmund, E. (2012). Pohybová aktivita populace. Olomouc: Univerzita Palackého.

27. Hamř́ík, Z., Sigmundová, D., Kalman, M., Pavelka, J. and Sigmind, E. (2013). Physical activity and sedentary behaviour in Czech adults: Results from GPAQ study. European Journal of Sport Science. ://dx.doi.org/10.1080/17461391.2013.822565

28. Jackson, R. J. and Kochtitzky, CH. (2001). Creating A Healthy Environment: Impact of the Built Environment on Public Health, Sprawl Watch (www.sprawlwatch.org/health.pdf), 2001

29. Hobza, V., Cikl, R. 2007. Subvenční politiky ve sportu a tělovýchově v České republice.

30. Česká kinantrolologie. Vol. 2, p. 67-82.
31. Kováŕ, R. 2002. Tělesná aktivita, tělesná zdatnost a zdraví. Česká kinantropologie 6, no. 1, p. 49-54.

32. Krejčík, V. (2006). “Základní principy zdravého životního stylu - sport a strava."

33. Lee, S., Shiroma, E. J., Lobelo, F., Puska, P., Blair., S. N. and Katzmarzyk, P. T. (2012). Effect of physical inactivity on major non-communicable diseases worldwidw: an analysis of burden of desease and life expectancy. The Lancet-Physical Activity Series. 380(9838). 9-19.

34. Litman, T. (2002). If Health: Integrating Public Health Objectives in Transportation Decision-Making, Victoria Transport Policy Institute (www.vtpi.org), 2002.

35. Litman, T. (2002a). Economic Value of Walkability, TPI (www.vtpi.org), 2002.

36. McElroy, M. 2002. A Social Analysis of Inactivity. Champaign, IL: Human Kinetics.

37. Michálek, J. and Sebera. M. (eds.). (2014). Výsledky šetření pohyové aktivity dospelé populace České republiky". Brno: Masarykova univerzita.

38. Morris, J. N. and Hardman, A. E. (1997). Walking to Health. Sports Medicine. May, vol. 23, no. 5, p. 306 332.

39. Nelson, P. et al. (2007). Physical activity and public health in older adults: Recommendation from the American College of Sports Medicine and the American Heart Association. Medicine Sportive Scientific Sports Exercise. 39:1435 - 1445, 2007.

40. Neuls, F. (2010). Walking and referred colerates in Czech adolescent girls. Gymnica, vol. 40, no. 30, s. 38. Olomouc: Univerzita Palackého.

41. Pink, B. (2008). Defining Sport and Physical Activity: a conceptual model. Cambera: Australian Bureau of Statistics.

42. Pratt, M. (2010). Physical activity and its economic impact on public health. Gymnica, vol. 40, no. 30, p. 23. Olomouc: Univerzita Palackého.

43. Rychtecký, A. 2007. Active Lifestyles of Young People - Benefits and Outcomes. Obesity

44. in Europe. Young People's Physical Activity and Sedentary Lifestyles. Berlin, Oxford: Peter Lang. p. $199-218$.

45. Rzewnicky, R. 2003. Health Enhancing Physical activity. Measurement and determinant of daily 
activity at home, work, travel, and leisure. Leuven: KU Leuven.

46. Sebera, M. (2014). Výzkumné šetření. Výsledky šetření pohyové aktivity dospelé populace České republiky". Brno: Masarykova univerzita, 50-52.

47. Sælensminde,K. (2002) Walking and Cycling Track Networks in Norwegian Cities: Cost-Benefit. Analysis Including Health Effects and External Costs of Road Traffic. Oslo: Institute of Transport Economics. (www.toi.no/toi_Data/Attachments/887/sum_567_02. pdf), 2002.

48. Sekot, A. (2014). Doprava do zaměstnání. Výsledky šetření pohyové aktivity dospelé populace České republiky”. Brno: Masarykova univerzita, p. 56-67.

49. Sekot, A. and Sebera M. (2014). Pohybové activity. Výsledky šetření pohyové aktivity dospelé populace České republiky". Brno: Masarykova univerzita, p. 68103.

50. Slepičková, I. (2001). Sport a volný čas adolescentů. Praha: FTVS UK.

51. Smart, B. (2005). The Sport Star. Modern Sport and Cultural Economy of Sporting Celebrity. London: SAGE Publications.
52. Staněk, M., Flemr, L. 2007. The role of local authorities of Czech cities in support of sport: A case studyof the capital city of Prague. Local Sport in Europe. EASS 4th Proceedings. Sutherland, D. H; et al. (1993). Kinematics of normal walking. Human walking. Baltimore: Williams and Wilkins. p. 23 - 44.

53. Schwartzhoffová, E. (2010). Cyclotourism in the Czech Republic. Gymnica, vol. 40, no.30, p. 39. Olomouc: Univerzita Palackého.

54. Vanreusel, B., Meulders, B. (2007). Sedentary lifestyles and physical (in-)activity in youth, a social risk perspective. Obesity in Europe. Young People's Physical Activity and Sedentary Lifestyles. p. 119 133. Berlin, Oxford: Peter Lang.

55. Valejt, Z. (2012). Současné vnímání sportu vysokoškolskou mládeží. Praha: ČVUT

56. Velký sociologický slovník. (2006). Praha: Vyšehrad

57. WHO (2003). A Physically Active Life Through Everyday Transport: With A Special Focus On Children And Older People And Examples And Approaches From Europe, World Health Organization, Regional Office for Europe (www.euro.who.int/document/e75662.pdf). 
